\title{
軟式野球ボールとバットの衝突シミュレーション*
}

\author{
神田芳 文*1, 鳴尾丈司*2
}

\section{Simulation of Impact between Rubber-ball and Bat for Baseball}

\author{
Yoshifumi KANDA*3 and Takeshi NARUO \\ ${ }^{* 3}$ Faculty of Science and Technology, Seikei University, \\ 3-3-1 Kichijoji-Kitamachi, Musashino-shi, Tokyo, 180-8633 Japan
}

\begin{abstract}
For a rubber baseball, which is a baseball made entirely of rubber, the softness of the ball makes it very difficult to increase the coefficient of restitution (COR) of the ball-bat impact by modifying the stiffness of the bat. In order to direct modification of the baseball bat, precise analysis of the impact phenomenon is required. In order to establish a powerfull tool for analyzing the baseball-bat impact, numerical analysis programs based on the three-dimensional finite element method have been developed. After verifying the developed programs by comparing calculated and experimental results, the impact characteristics of an aluminum bat in collision with a rubber baseball were investigated precisely. The results show that the COR decreases with increasing impact velocity, and that the COR is greatly affected by the hoop rigidity of the barrel of the bat, which has a hollow shell structure. Moreover, at high impact velocities, the COR is maximized at an impact location about $600 \mathrm{~mm}$ from the end of the bat handle.
\end{abstract}

Key Words : Baseball Bat, Rubber Ball, Finite Element Method, Impact, Contact Problem, Modal Analysis

\section{1. 緒言}

野球バットの反発性能に関する研究はかなり活発に 行われている(1),(2),(3) が，そのほとんどは硬式野球あ るいはソフトボールに関するものであって, 軟式野球 バットに関する研究はほとんど見当たらない.しかる に，軟式野球の競技人口は約 120 万人 (4) といわれ ており，軟式野球バットの反発向上を筆頭とする高性 能化への要望は非常に高いものがある．さらに，軟式 野球ボールは硬式野球ボールあるいはソフトボールに 比して著しく柔らかく，バットの剛性変更による反発 向上が極めて困難であるという問題が存在している.

このような背景にあって，軟式野球のボールとバッ トの衝突解析を簡便に，高精度で行える信頼性と実 用性に富む解析システムの開発が, 高反発の軟式野球 バットの開発にとって急務であるといわざるを得ない. 加えて, 商用の汎用有限要素解析システムの使用では 理想とする簡便で高精度の解析を短時間で行うには無 理があり, 軟式野球のボールとバットの衝突解析に特 化した 3 次元有限要素解析システムを独自に開発する

* 原稿受付 2006 年 10 月 5 日.

*1 正員, 成蹊大学理工学部( $180-8633$ 武蔵野市吉祥寺北町 3-3-1).

*2 正員, ミズノ(株) (五559-8510 大阪市住之江区南港北 1-1235).

E-mail : kanda@st.seikei.ac.jp
ことが望ましいと考えられる，幸い，著者の一人はす でに (5),(6), 有限要素法を用いてテニスのボールとラ ケットの衝突解析を十分に実系に忠実なモデルで簡便 に高精度の解析が可能なシステムの開発を完了してい る. 本報ではその実績に立脚して, 軟式野球用アルミ ニウム製金属バットと軟式野球ボールの衝突解析に特 化した実用性と信頼性の高い3 次元有限要素解析シス テムの開発を行った.

ボールおよびバットの 3 次元有限要素モデルを構築 し, 衝突解析手法を確立し, 衝突解析を行って, 実験 と対比することにより解析システムの精度および有効 性を検証した後, ボールの衝突速度, 衝突位置の変化 が反発係数に与える影響, 仮想的にバットの剛性を変 化させたとき，バットの曲げ剛性および偏平剛性が反 発係数に与える影響などを調べた.

\section{2. 有限要素モデルおよび解析方法}

$2 \cdot 1$ ボールモデル 軟式野球ボールの有限要素 モデルの構築方法および有限要素解析手法はテニス ボールに関するもの(5),(6) と基本的に同じである.モ デル化の対象とする実物の軟式野球ボールは全日本 軟式野球連盟公認球（ケンコーボールA号）である. ボールのゴム皮膜のモデル化には，有限ひずみを考慮 した 16 節点アイソパラメトリック六面体要素を用い 


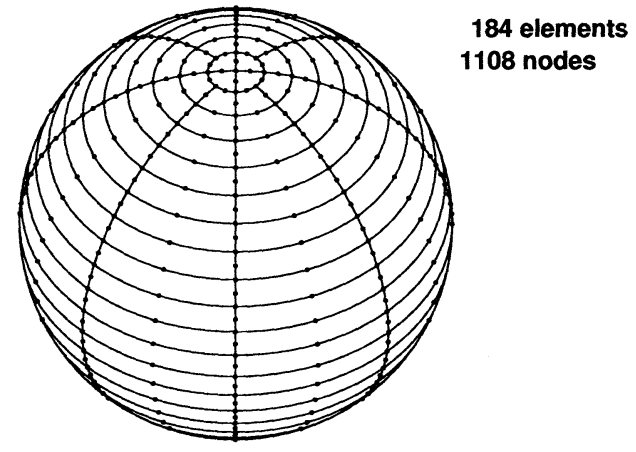

Fig. 1 Finite element model of a ball using hexahedron element

た. 本要素はボールのゴム膜の厚さ方向には 1 次の内 挿関数を，それと直交して曲面を構成する 2 方向には 2 次の内插関数をもつもので，2次要素としての利点 を生かしつつ経済化のために節点数の増加を抑えたも のとなっている.

この六面体要素を用いたボールの有限要素モデル を図 1 に示すが，図中に見えないボールのゴム膜の厚 さ方向は 1 要素に分割している. ボールのゴム材の ヤング率は, 試験片の引張試験によって得られた非線 形の応力-ひずみ線図をもとに, 等価線形的な一定值 $4.81 \mathrm{MPa}\left(0.49 \mathrm{kgf} / \mathrm{mm}^{2}\right)$ と同定した. ボールの初期状 態における諸量は実測により求め, 外直径は $72.17 \mathrm{~mm}$, ت゙ム厚さは実測平均値 $7.8 \mathrm{~mm}$ の一定厚さ, 内封気体の ゲージ圧力は $8.826 \times 10^{4} \mathrm{~Pa}\left(0.9 \mathrm{~kg} f / \mathrm{cm}^{2}\right)$, 質量は $136 \mathrm{~g}$ とした.

ゴム被膜によって内封された気体はボールの変形に 従って体積が変化し, それに応じて内部圧力も変化す る. この熱力学的変化をポリトロープ変化と考えれば, 内封気体の体積を $V$, 圧力を $p$, その初期状態におけ る值をそれぞれ $V_{0}, p_{0}$ とし，ポリトロープ指数を $n$ とすれば，次式が成り立つ。

$$
p V^{n}=p_{0} V_{0}^{n}
$$

ポリトロープ指数 $n$ は, ボールの静的圧縮試験とそれ に相当する解析を行い, $n=1.4$ と同定した. (1) 式の 成立は中心差分法の $k$ ステップ目における内封気体の 圧力 $p_{k}$ を前ステップにおける内封気体の体積 $V_{k-1}$ か ら次式により求めることで近似的に強制した.

$$
p_{k}=p_{0}\left(\frac{V_{0}}{V_{k-1}}\right)^{n}
$$

$2 \cdot 2$ バットモデル 解析システムの妥当性を検 証する目的で, 実在する 2 本のバットによる実験と解

\begin{tabular}{|c|c|c|c|}
\hline \multicolumn{2}{|l|}{ Tested bat } & \multirow{2}{*}{ 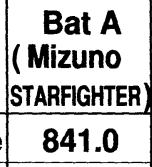 } & \multirow{2}{*}{\begin{tabular}{|c}
$\begin{array}{c}\text { Bat B } \\
\text { (Mizuno } \\
500 G S)\end{array}$ \\
840.0 \\
\end{tabular}} \\
\hline Total length & Prototype & & \\
\hline & Model & 841.0 & 840.0 \\
\hline \multirow{2}{*}{$\begin{array}{r}\text { Total mass } \\
{[\mathrm{g}]}\end{array}$} & Prototype & 820.0 & 739.0 \\
\hline & Model & 821.1 & 740.9 \\
\hline \multirow{2}{*}{$\begin{array}{c}\text { Center of gravity } \\
\text { from grip end } \\
\text { [mm] }\end{array}$} & Prototype & 514.0 & 492.0 \\
\hline & Model & 514.0 & 489.5 \\
\hline \multirow{2}{*}{$\begin{array}{c}\text { Moment of inertia } \\
\text { about COG } \\
{\left[\mathrm{kgm}^{2}\right]}\end{array}$} & Prototype & 0.0549 & 0.0530 \\
\hline & Model & 0.0506 & 0.0485 \\
\hline \multirow{2}{*}{$\begin{array}{c}\text { Center of percussion } \\
\text { with respect to } \\
110 \mathrm{~mm} \text {-point from } \\
\text { grip end [mm] }\end{array}$} & Prototype & 682.0 & 683.0 \\
\hline & Model & 666.5 & 662.0 \\
\hline
\end{tabular}

Table 1 Physical properties of aluminum bats

析を行った. 本報で対象とした軟式野球用アルミニウ ム製バットの型式および物理特性を表 1 に示す. 金属 バットは構造的には比較的厚みのある円筒シェルであ り，しかもシェルの面内剛性および面外剛性が共に重 要となる問題であって, 解析は容易ではない. 従って, 有限要素の選択は慎重でなければならない. 接触問題 においては要素表面に節点が配置された要素の方が接 触状態の把握の点からは望ましい. そこで, ボールと 同様に 16 節点アイソパラメトリック六面体要素でバッ トをモデル化することを試みた．しかし，このような ソリッド要素をシェルとして用いた場合, バットの固 有振動解析 (3.2 節参照) における 1 次偏平 (hoop) 振 動の振動数は実測值と比べて $+14.5 \%$ 程度の誤差を生 ずる結果となり, 面外剛性すなわちバットの偏平剛性 の精度が著しく悪いと判断し, 使用を断念した.

偏平剛性の精度改善のため; シェル要素によりバッ トをモデル化した．シェル要素は節点がシェルの中立 面にあって, 要素表面にはない. そのため, 接触問題 に使用寸る際には何らかの工夫が必要となるが，接触 のチェックにおいては節点を板厚方向に中立面から表 面にオフセットさせて対応した. シェル要素に関して も板厚, 曲率, 負荷, 要素分割数により精度が著しく 異なり, シェルとしてのすべての状況に対応可能な高 精度の要素は現状存在しないと考えるのが妥当であ る. それ故, シェル要素の選択にも十分な配慮が要求 される.

厚肉シェルとして利用可能な degenerated shell element のうち, 積分次数の低減により shear locking 防止を行った 4 節点および 9 節点四辺形変位法要素と 4 節点四辺形混合法要素 (7) の 3 要素を, 片持ち円筒 


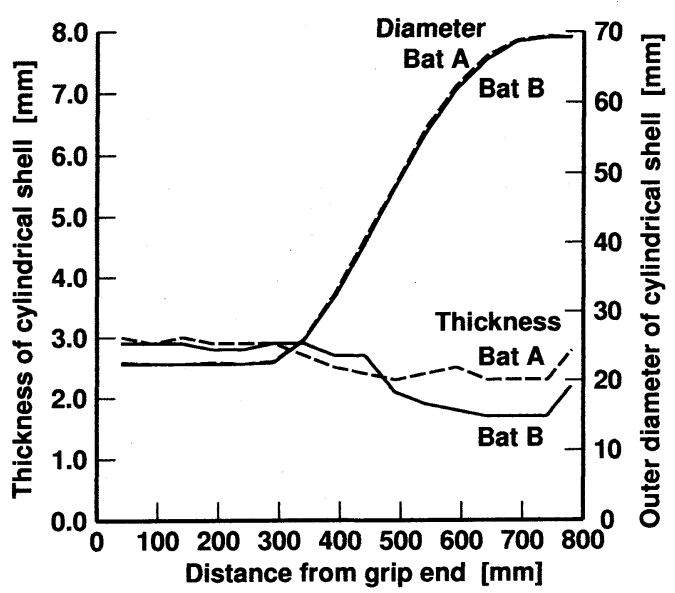

Fig. 2 Longitudinal variations of outer diameter and thickness

シェルの固有振動解析などを行った結果と, 実測結果 との比較により評価し，より良好な精度が得られた 4 節点四辺形混合法要素を本解析において採用した.

実在バットは外径, 肉厚が長手方向に変化しており, その実測データを図 2 に示す. モデル化においては, これらの変化をできるだけ正確に表現できるよう配慮 した。

バットの有限要素モデルを図 3 に示すが, バットの 長手方向にはほぼ $5 \mathrm{~mm}$ 間隔の分割であり, 円筒の周 方向には 48 分割になっている. バットのアルミニウ ム材のヤング率は $68.7 \mathrm{GPa}\left(7000 \mathrm{~kg} / \mathrm{mm}^{2}\right)$, ポアソン 比は 0.33 , 密度は $2.9 \mathrm{~g} / \mathrm{cm}^{3}$ とした. こうして得られ た有限要素モデルの物理特性を表 1 に示す. 慣性モー メントに実在バットとの差が若干みられるが, 全体的 にモデルと実在バットの物理特性はよく一致している といえる.

$2 \cdot 3$ 解析方法 非線形性を呈する要因としては, ボールの幾何学的非線形性および材料非線形性, ボール
とバットの接触が挙げられる. 金属バットについては幾 何学的にも材料的にも線形として扱うことに問題はな いと考えられる. ボールの材料非線形性については等 価的な一定值のヤング率を特定することにより, 線形 化して扱った. 幾何学的非線形性は Updated Lagrange 形式の増分法により考慮した. 接触問題の解析には Penalty 法を用いた.

続いて, ボールとバットの衝突における運動方程式 とその解法について述べる. まずボールの運動方程式 は, 質量マトリックスを $[M]$, 変位ベクトルを $\{d\}$, 内 カベクトルを $\{p\}$, 外力ベクトルを $\{f\}$, ・を時間に関 する微分として次式で表される.

$$
[M]\{\ddot{d}\}=-\{p\}+\{f\}
$$

減衰の考慮は実際の衝突現象をシミュレートするに は不可欠であるが, 本システムにおいては, ボールに 関しては要素レベルで単純 Voigt モデルの粘弾性を仮 定した. このとき, 要素内の态力, ひずみ, ひずみ速 度をそれぞれ $\{\sigma\},\{\varepsilon\},\{\dot{\varepsilon}\}$ とし, 弾性係数行列, 粘性 係数行列をそれぞれ $[D],[H]$ とすると次式が成立する.

$$
\{\sigma\}=[D]\{\varepsilon\}+[H]\{\dot{\varepsilon}\}
$$

粘性係数行列 $[H]$ の設定には，何らかの仮定が必要と なるがここでは，

$$
[H]=\beta_{\text {ball }}[D]
$$

を仮定する. 実験との対比を通して係数 $\beta_{\text {ball }}=$ $2.2 \times 10^{-4} \mathrm{sec}$ と同定した.

次にバットの運動方程式は, 変位ベクトルを $\{x\}$, 質 量マトリックスを $[m]$, 減衰マトリックスを $[c]$, 剛性 マトリックスを $[k]$, 外力ベクトルを $\{f\}$ とすれば次 式で表される.

$$
[m]\{\ddot{x}\}+[c]\{\dot{x}\}+[k]\{x\}=-\{f\}
$$

\section{8 elements 8210 nodes}

Fig. 3 Finite element model of a bat using quadrilateral shell element 
ここで, バットの減衰に関してボールと実質的に同様 の扱いとなるよう $[k]$ に比例する比例減衰

$$
[c]=\beta_{b a t}[k]
$$

を仮定するものとする.

運動方程式の解法には, 直接時間積分陽解法である 中心差分法を用いた．その際，そもそもバットの剛性 がボールの剛性に比べて非常に高いこと, 偏平剛性の 精度を確保するためバットの要素分割がかなり細かく なったことに起因して, 中心差分法の時間きざみを著 しく小さくとる必要性が生じてしまい, 害用的な解析 が不可能になるという問題に直面した.

この問題を回避するため, バットは線形の挙動であっ てしかも比較的低次の振動モードのみが衝突現象に関 与寸ることから，バットについては固有振動解析から 得られた固有振動モード $[\phi]$ を用いて物理座標 $\{x\}$ か らモード座標 $\{\xi\} へ$,

$$
\{x\}=[\phi]\{\xi\}
$$

に従って変換し，その際に高次モード成分をカットす ることを行った．具体的には低い方から 20 個のモー ド成分のみを残すこととした．このとき，バットの運 動方程式は各モード $n$ ごとに分離され, 固有角振動数 を $\omega_{n}$ として次式で表される.

$$
\ddot{\xi}_{n}+\beta_{b a t} \omega_{n}^{2} \dot{\xi}_{n}+\omega_{n}^{2} \xi_{n}=-\sum_{i} \phi_{i n} f_{i}
$$

この式における比例係数 $\beta_{b a t}$ は実験との対比を通して $\beta_{\text {bat }}=2.0 \times 10^{-5} \mathrm{sec}$ と同定した.

以上のようにして, ボールは物理座標で, バットは モード座標で記述して, 物理座標とモード座標の混 在した運動方程式を解いていくこととした。こうする ことによって，時間きざみをボールのみの解析と同じ $10^{-8}$ 秒のままで, バットーボール全系に対して安定に かつ精度低下を招くことなく解析できた。 さらにバッ トの衝突特性を議論する上で, 振動モードごとの寄与 を調べることが容易になった.

\section{4 接触面 ボールとバットの摩擦を伴う接触} は以下のようにして扱う。ボールとバットの接触は物 理的には面と面の接触であるが, 本報においてはボー ルの表面とバットの節点の接触として扱う。 その際, ボールとバットの貫通を完全に抑えることが難しいの で, バットのメッシュ分割を細かくして実用上の問題 回避を行った. また，シェル要素を採用したことから バットの表面には節点はないので, シェル要素の中立

\begin{tabular}{|c|c|c|c|c|c|}
\hline \multicolumn{2}{|c|}{ Initial condition } & \multicolumn{4}{|c|}{ Obtained results } \\
\hline $\begin{array}{l}V_{\text {Ball }}^{(\text {in) }} \\
{[\mathrm{m} / \mathrm{s}]}\end{array}$ & $\begin{array}{l}\theta_{0} \\
\text { [deg] }\end{array}$ & & $\begin{array}{l}V_{\text {Ball }}^{\text {(out) }} \\
{[\mathrm{m} / \mathrm{s}]}\end{array}$ & $\begin{array}{l}\theta_{1} \\
\text { [deg] }\end{array}$ & $\begin{array}{c}\omega_{1} \\
{[\mathrm{rad} / \mathrm{s}]}\end{array}$ \\
\hline \multirow{2}{*}{18.4} & \multirow{2}{*}{0.0} & Calculated & 11.01 & 0.0 & 0.0 \\
\hline & & imental & & 0.0 & 0 \\
\hline \multirow{2}{*}{18.3} & \multirow{2}{*}{15.9} & Calculated & 10.97 & 12.62 & 67.3 \\
\hline & & Experimental & 11.2 & 12.9 & \\
\hline \multirow{2}{*}{18.2} & \multirow{2}{*}{28.3} & Calculated & 11.00 & 22.32 & 117.0 \\
\hline & & Experimental & & 23.8 & 117 \\
\hline \multirow{2}{*}{18.5} & \multirow{2}{*}{43.9} & Calculated & 11.26 & 33.68 & 183.0 \\
\hline & & Experimental & 11.7 & 35.4 & 182 \\
\hline \multirow{2}{*}{18.3} & \multirow{2}{*}{58.1} & Calculated & 10.82 & 46.31 & 259.4 \\
\hline & & nental & & 46.5 & 272 \\
\hline \multirow{2}{*}{18.1} & \multirow{2}{*}{73.8} & Calculated & 12.53 & 71.26 & 232.2 \\
\hline & & ntal & & 72.1 & 240 \\
\hline \multirow{2}{*}{12.0} & \multirow{2}{*}{0.0} & Calculated & 8.05 & 0.0 & 0.0 \\
\hline & & Experimental & & 0.0 & 0 \\
\hline
\end{tabular}
面上の節点をシェル板厚方向に表面までシフトして扱
Table 2 Collision of a rubber-ball on rigid wall

った.

ボールとバットの接触が想定される範囲において, バットの表面にシフトした節点に関して最も近くなる ボール表面上の点を特定し（どの要素のいかなる局所 座標值であるかを求め), この点とシフトしたバットの 節点との間の距離をチェックし, 接触中はこの 2 点間 にペナルティパラメータを設定した. シフトしたバッ 卜節点とボール表面の距離を $d$, ボールとバットの間 に働く接触力の接触面に垂直な成分を $f_{n}$, すべり方向 成分を $f_{s}$, ボールとバットの静止摩擦係数を $\mu_{s}$, 動摩 擦係数を $\mu_{d}$ とする. 接触の状態としては, 非接触, 固 着, 相対すべりの三つを考える. 非接触状態は $d>0$ のときで, $f_{n}=f_{s}=0$ となる. 固着状態は $d=0$ かつ $f_{s}<\mu_{s} f_{n}$ のときで, シフトしたバットの節点とボール の表面の接触点は同一の変位となる. 相対すべり状態 は $d=0$ かつ $f_{s} \geq \mu_{s} f_{n}$ のときで, ボールおよびバット はすべりと逆方向に $\mu_{d} f_{n}$ の摩擦力を受ける.

これらの諸条件を増分計算の各ステップでチェック し, 矛盾がある場合は接触状態を変更し矛盾を解消し つつ計算を進めていく．本報においてはボールとバッ トの間の摩擦係数は $\mu_{s}=\mu_{d}=0.61$ とした ${ }^{(8)}$.

\section{3. 解析および考察}

3.1 ボールの剛体壁面への衝突解析 スピンの ない軟式野球ボールが剛体の壁面に入射速度 $V_{\text {ball }}^{(i n)}$, 入 射角 $\theta_{0}$ で衝突する現象の, 反射速度 $V_{\text {ball }}^{(\text {out })}$, 反射角 $\theta_{1}$, 反射角速度 $\omega_{1}$ を解析と実験で求めて比較した.

実験はボール発射装置により発射したボール（使用 球 : ケンコーA号）を鋼製ブロックに衝突させ，その 状態を高速度ビデオカメラ (PHOTRON FASTCAMPCI）により 1000 コマ/秒で撮影し，撮影画像を解析 することにより行った. 解析および実駼結果を表 2 に 
Table 3 Natural frequencies of aluminum bats

\begin{tabular}{|c|l|c|c|}
\hline \multicolumn{2}{|c|}{ Mode } & \multicolumn{2}{c|}{ Frequency [Hz] } \\
\cline { 3 - 4 } & \multicolumn{2}{|c|}{ Bat A } & Bat B \\
\hline \multirow{2}{*}{ 1st bending } & Experimental & 197.5 & 195.0 \\
\cline { 2 - 4 } & Calculated & 196.8 & 193.1 \\
\hline \multirow{2}{*}{ 2nd bending } & Experimental & 697.5 & 690.0 \\
\cline { 2 - 4 } & Calculated & 696.5 & 683.1 \\
\hline \multirow{2}{*}{ 1st hoop } & Experimental & 1640 & 1302 \\
\cline { 2 - 4 } & Calculated & 1644 & 1296 \\
\hline
\end{tabular}

示すが，両者は良好に一致しており，ボールの衝突解 析の正当性が裹づけられた。

3.2 バットの固有振動 バットの基本振動特性 を知るため, バットの固有振動について実験と解析を 行った. バットの支持条件は全周囲自由である. 衝突 に関与するとされるバットの曲げ振動の 1 次および 2 次振動, 円筒の 1 次偏平（hoop）振動につき調べた. 結果を表 3 に示すが, 実験結果と解析結果は非常に良 く一致している. バットAとバットBの比較をすれば, 曲げ振動に関しては固有振動数の差がほとんどないの に対して，偏平振動の固有振動数は明確に異なってい る.これは, 打撃中心付近のシェル板厚の差に起因す ると考えられる.

3.3 ボールとバットの衝突解析 衝突の状態と しては, 静止した全周囲自由なバットにスピンのない ボールがバットの長手方向軸に垂直に衝突する場合を 扱う。この場合, ボールの入射速度を $V_{b a l l}^{(\text {in })}$, 反射速 度を $V_{b a l l}^{(o u t)}$, バットの衝突後の重心速度を $V_{b a t}^{(p a l .)}$, 重 心周りの回転角速度を $\omega_{b a t}^{(r o t .)}$, グリップ側を正とする ボールの衝突位置とバットの重心位置の距離を $a$ とし, バットの弾性変形を無視すれば, 反発係数 $e$ は次のよ うに与えられる.

$$
e=-\frac{V_{b a l l}{ }^{(o u t)}-\left(V_{b a t}^{(p a l .)}+a \omega_{b a t}^{(\text {rot. })}\right)}{V_{b a l l}^{(i n)}}
$$

衝突実験は，バットを床に水平になるようにバット 置き台の上に乗せ, ピッチングマシーンにより床に水
平でかつバットに垂直になるようにボールを発射させ て，その際の衝突現象を上方から高速度ビデオカメラ (PHOTRON FASTCAM-PCIにて 1000 コマ/秒) で撮 影することにより行った. そこで得られた画像を解析 することにより (10) 式の右辺の各未知量が測定され, 反発係数が求まる. ボールの衝突位置はまずは打撃中 心 (グリップ端より $683 \mathrm{~mm}$ の位置) に設定した. ボー ルの発射速度を一定にすることは困難なため, 入射速 度 $34 \mathrm{~m} / \mathrm{s}$ を目安に発射された数回の衝突実験の平均値 をもって実験結果とし, 実測平均值の入射速度で入射 する場合の衝突について解析を行って比較した. その 結果を表 4 に示す.

表 4 の解析結果と実験結果を比較すれば, 衝突後の 速度および角速度については数量的にかなり良く合っ ており, バット Aとバット Bの特性の違いも計算結果 から読み取ることができ, 反発係数については数值的 に非常に良く一致している，バットAとバットBの反 発係数が一致しているのは単なる偶然であって, バッ トAはバットBよりも質量が $81 g$ 重いことによる高反 発の効果と, バット BはバットAよりも打撃中心付近 の肉厚が $0.6 \mathrm{~mm}$ 程度薄いことによる高反発の効果が たまたま同程度であったと解釈するのが妥当であろう.

次に, ボールの入射速度と衝突位置を変化させて, 反発係数がどのように变わるかについてバットBに関 して調べた. 詳細に速度を変えた解析を行う前に解析 の正当性を検証するため, ボールの入射速度が $17 \mathrm{~m} / \mathrm{s}$ と $34 \mathrm{~m} / \mathrm{s}$ の場合について, 実験と解析を行いそれらの 結果を比較した. 結果を図 4 に示すが, 実験結果と解 析結果が非常に良く一致していることがわかる. 続い て細かくボールの衝突速度を変えた解析を行った， そ の結果が図 5 である.この図より,ボールの衝突速度 が増すにつれて反発係数は明確に減少すること, ボー ルの衝突速度が低速および中速の場合にはバットの先 端に近い位置に衝突するほど反発係数が小さくなるこ と, 衝突速度が高速の場合にはグリップ端より $600 \mathrm{~mm}$ 付近の衝突位置で反発係数が最大になる傾向があるこ となどがわかる.

Table 4 Pre- and post-impact velocities and coefficient of restitution (COR) [impact location:683mm]

\begin{tabular}{|c|c|c|c|c|c|c|}
\hline & $\begin{array}{r}\text { Velocity and } \\
\text { COR }\end{array}$ & $\begin{array}{l}\begin{array}{l}V_{\text {ball }}^{(\text {In) }} \\
{[\mathrm{m} / \mathrm{s}]}\end{array} \\
\end{array}$ & $\begin{array}{l}\begin{array}{l}V_{\text {Vaut }}^{\text {(ourt }} \\
{[\mathrm{m} / \mathrm{s}]}\end{array} \\
\end{array}$ & $\begin{array}{l}\begin{array}{l}\mathbf{V}_{\text {bat }}^{\text {(pal) }} \\
{[\mathrm{m} / \mathrm{s}]}\end{array} \\
\end{array}$ & $\begin{array}{l}\omega_{\text {bat) }}^{\text {(rot) }} \\
{[\mathrm{rad} / \mathrm{s}]}\end{array}$ & COR \\
\hline \multirow{2}{*}{ Bat A } & Experimental & 34.05 & -6.75 & 7.04 & 22.13 & 0.514 \\
\hline & Calculated & 34.05 & -7.32 & 7.09 & 9.81 & 0.521 \\
\hline \multirow{2}{*}{ Bat B } & Experimental & 34.26 & -5.23 & 7.56 & 25.26 & 0.514 \\
\hline & Calculated & 34.26 & -5.67 & 7.70 & 23.07 & 0.519 \\
\hline
\end{tabular}




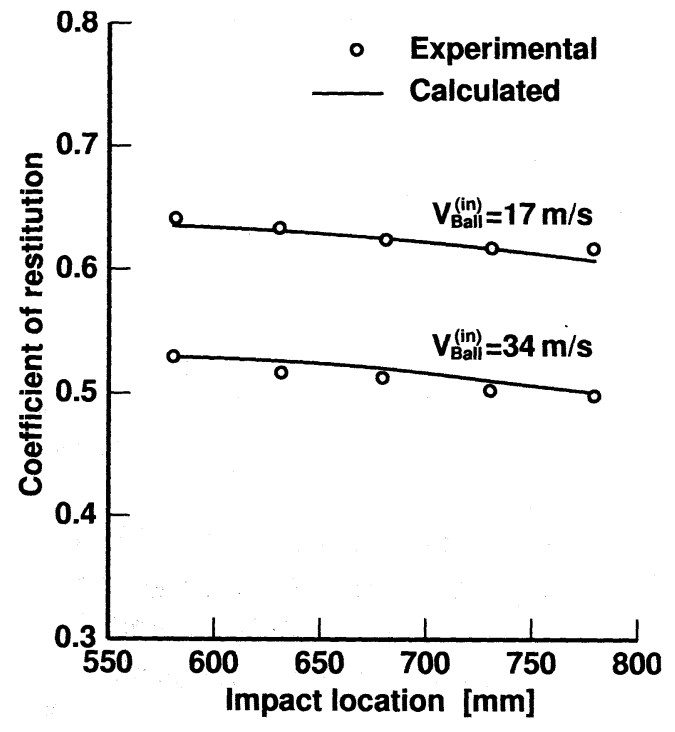

Fig. 4 Calculated and measured coefficient of restitution vs. impact location from end of bat handle

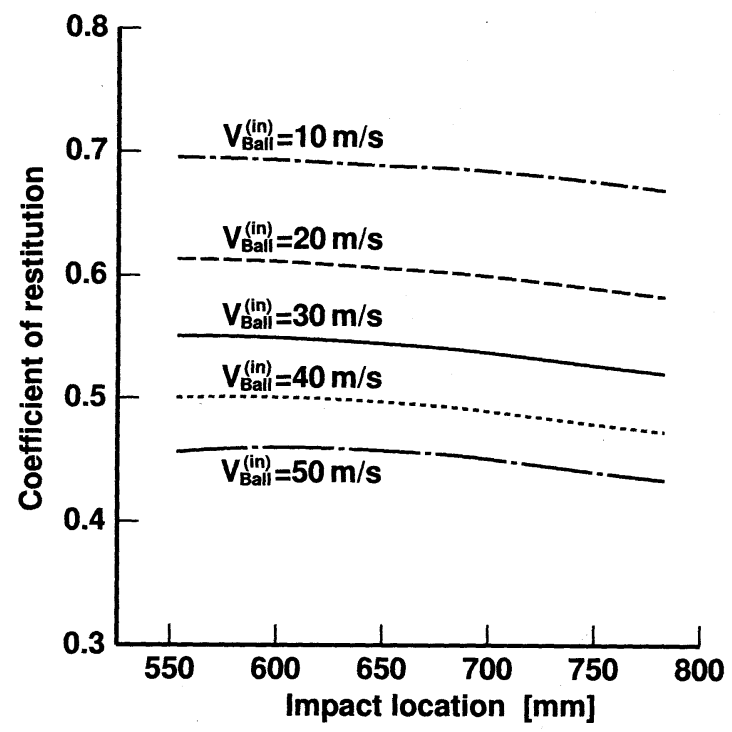

Fig. 5 Effects of incident ball velocity and impact location from end of bat handle on coefficient of restitution

最後に，バットの剛性変化が反発係数に与える影響 について解析した. バットBを標準バットとし, 仮想 的に剛性を変えるためヤング率を標準バットの $r_{s}$ 倍 としたバットの反発係数を解析した. $r_{s}$ を剛性比と呼 ぶことにする． $r_{s}$ を 0.1 から 30 まで連続的に変えた

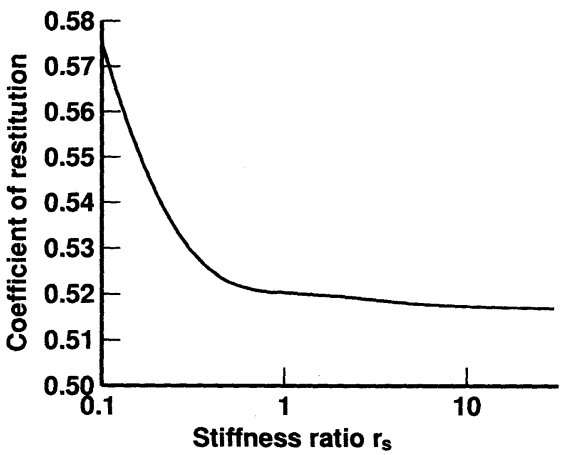

Fig. 6 Effect of bat stiffness on coefficient of restitution $\left(V_{\text {ball }}^{(i n)}=34 \mathrm{~m} / \mathrm{s}\right.$, impact location:683mm)

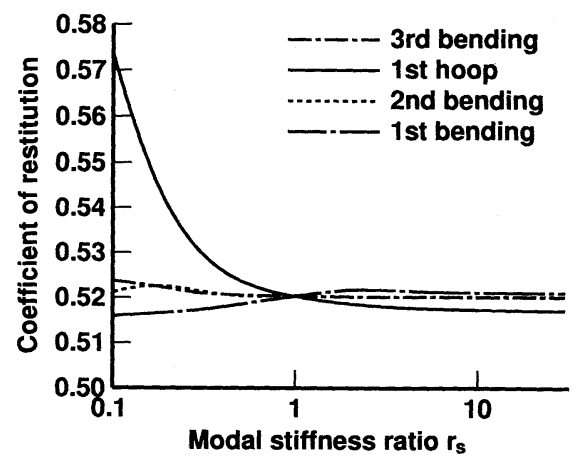

Fig. 7 Effect of bat modal stiffness on coefficient of restitution $\left(V_{b a l l}^{(i n)}=34 \mathrm{~m} / \mathrm{s}\right.$, impact location:683mm)

ときの反発係数の変化について, 入射速度を $34 \mathrm{~m} / \mathrm{s}$, 衝突位置を打撃中心 (グリップ端より $683 \mathrm{~mm}$ の位置) として解析した結果を図 6 に示寸.この図より, 標準 バットの剛性を高めてみても反発係数はほとんど変わ らないことおよび標準バットの剛性を十分に低くした ときには反発係数が増加することがわかる.

図 6 に表された変化に関して, バットの固有振動モー ドに関係したモード剛性ごとの寄与を調べるため, 特 定の単一の振動モードのモード剛性だけを $r_{s}$ 倍に変 化させて反発係数の変化を調べた. 結果を図 7 に示す が, 反発係数に与えるバット剛性の影響としては偏平 剛性の影響が圧倒的に大きいことが一目瞭然であるこ と, バットの曲げモード剛性の影響については, 衝突 位置と振動の節との距離の影響があって衝突位置が大 きく異なる場合は別として, 通常の打撃の中央付近と される打撃中心（1 次， 2 次， 3 次の曲げ振動の節と それぞれ $26.9 \mathrm{~mm}, 34.5 \mathrm{~mm}, 66.0 \mathrm{~mm}$ の距離）を衝突 
位置とする図 7 の場合については，1 次曲げモード剛 性の増加は 2 倍程度までならば若干ではあるが反発係 数を高めること, 2 次および 3 次の曲げモード剛性は 反発係数に寄与していないことがわかる.

\section{4. 結言}

軟式野球用のボールと金属バットの衝突現象を正確 に解析できる 3 次元有限要素解析システムを開発し, いくつかの実験結果と解析結果と対比して良好な一致 が得られたことから，解析システムの妥当性が検証で きた.さらに，ボールの衝突速度および衝突位置，バッ 卜の剛性を変えて衝突解析を行い, 以下のような知見 を得た。

（1）衝突速度が高くなるにつれ，反発係数は明確に 低下する.

（2）衝突速度が低速および中速の場合には衝突位置 がバット先端に近いほど反発係数は小さく, 衝突速度 が高速の場合にはバットの打撃中心よりややグリップ 端寄りに反発係数が最大になる衝突位置が存在する.

（3）バットの剛性のうち反発係数に与える影響が圧 倒的に大きいのは偏平剛性であって, 偏平剛性が低い ほど反発係数は大きくなる.

本解析システムを軟式野球バットの設計に適用して, 実現が困難とされている軟式野球バットの反発性能の 向上を図ることが可能になることを期待している.

最後に，バットの肉厚計測および衝突計測の一部に
多大のご助力を賜ったミズノ（株）商品開発部用具開 発課御園和則氏に深く謝意を表する.

\section{文献}

(1) Naruo,T. and Sato,F., Performance of a baseball bat, Proceeding of the fifth Japan International SAMPE Symposium,(1997),pp1311-1316.

(2) Nathan,A.M. et al., The Physics of the Trampoline Effect in Baseball and Softball Bats, The Engineering of Sport 5,2,(2004),pp.38-44,ISEA.

(3) Smith,L.V. et al., How Bat Modifications Can Affect Their Response, The Impact of Technology on Sport,(2005),pp.33-38,Australasian Sports Technology Alliance Pty Ltd.

(4) JSBB Website, http://www.jsbb.or.jp

(5) Kanda,Y., Finite Element Analysis of Impact of a Ball on a Tennis Racket (Impact Characteristics of Racket), Transactions of the Japan Society of Mechanical Engineers, Series C,Vol.64,No.625(1998),pp.3383-3390.

(6) Kanda,Y. et al., Estimation of Tennis Racket Power Using Three-dimensional Finite Element Analysis, The Engineering of Sport 4,(2002),pp.207-214,Blackwell Science Ltd.

(7) Kanda,Y., New Elements Derived from One Type of Mixed Formulations(Shell Element and its Applications to Vibration Problems), Journal of the Society of Naval Architects of Japan, Vol.148(1980),pp.232-242.

(8) Kanda,Y. and Nagao,H., Restitution Characteristics of a Rubber-ball for Baseball, Proceedings of the Symposium on Sports Engineering 2003,No.03-12(2003-11),pp.119124. 